4. 'Tuerefore', we would recommend that the Buncombe County Medical society and all its members binds itself and themselves by a rritten agreement to make no insurauce examinations for less than the usual ree of $\$ 5.00$, save that when a company is willing to omit the family history and urinalysis. thus very materially less ening the work of such an examination, the membirs of this societ will agree 10 make $\$ 3$ the regular charge.

5. That the secretary be directed to obtain within two weeks the simatures of each and every member to this resolution and to each one a copt of this report showing that the interest of this movement.

i. Firther, that all physicians in cood standing in the county, even when not member's of this society, be urged to join with us in this movement.

7. That the secretary be directed to send a copy of these resolutions to the secretaly of each county society in this state, and to the state society, with the reguest that they be read at the next meeting, and that similar !esolutions be passed by them; for un less the profession as a whole realizes that only in union is strength and stand together. it is easy to foresee the coming of the time when the companies, seeing their power in our disunion, will further reduce the tee. till as in Germany and France it present, a phssician will be oblimed to take fees of 50 cents and loss for slilied work, which is none too largely naid at present rates.

8. That to further the largely paid at present rates. ment the to further the fight to TIIE Jolrest. of the American Medical Association, with the reguest that they be published in its columns.

Charles T. Mrxor,

M. H. FLETCHER,

Committee.

OKLAHOMA MEDICAL ASSOCIATION

At the annual session of this association, held at Oklahoma City, May $7-9,1906$, the following resolution was passed:

Whrreas, We, the members of the Oklahoma State Medical Assoiation, in convention assembled, ever ready to promote the genera welfare of the people. corporations and bodies we serve, and mindfu of the duties imposed and services reguired of us by these people believe that it is not for the best interests of all concerned tha onr examination fees be reduced, but that it rather tends to lowe the dignity and cause us to become more lax in our examination and thereby render poorer service to our constituents, all of which is subversive of any good, and believing. as we do, that all good people, corporations and bodies demand the best service that we can lender and should be willing to pay a just compensation for such service, and further helieve that it is the practice of poor economy by any corporation, to lower examination fees and still demand the same service, and that this association should use its influence with all the people, corpolations and bodies demanding our services, and endeavor to impress on them the necessity of paying what the services al'e really worth. Therefore be it

Resolved, That the Oklahoma State Medical Association recom mends that each constituent organization of this body take the proper steps to establish a minimum fee of $\$ 5.00$ for each and ever examination made; that this society condemns contract practice. and hereafter our members be forbidden to accept the same unIes paid for at the regularly established rate.

Tohy Raysoy HaMiLL, Guthrie. Chairman.

Frovd E. WaRTERFIELD, IIoldenville.

W. F. DICKFx, Oklahoma Cits.

COLUMBIA (s. c.) MEDICAL SOCIETY.

It a recent meeting this society formally adopted the resolutions regarding insurance fees, passed by the South Carolina Medical Association, published in Tme Jocrnal May 5, 1906, page 1386

SACRAMENTO SOCIETY OF MEDICAL IMPROVEMENT.

Sacramento, Cal., April 25, 1906.

At a regular meeting, held April 24, 1906, the following preamble and resolutions were unanimously adopted:

Whereas, Several of our members have been notified that the Mutual Life Insurance Company of New York has reduced the fee for the examinatoion of applicants from five $(\$ 5)$ to three $(\$ 3)$ dollars, and

WHERFAS, These members have referred this action to our society, which, for many years, has had in force a fee bill rate for such examinations for old line companies of five (\$5) dollars, and,

WHEREAS, The last-named figure for a full and complete examivation, with analysis of urine, filling blanks and necessary corre spondence, is but a fair compensation for the time occupied by professional men on whose honesty and capability the success of life nsurance companies must mainly rest; it is therefore,

Resolved, That the members of the Sacramento Society for Medical Improvement agree to adhere to thelr fee bill rate and earnestly protest against the reduction made by the present officers of the Mutual Life Insurance Company of New York, as unjust, unfair, and unworthy, and they recommend all medical men in affiliation with the State Medical Society, and the American Medical Associaofficers of which have taken this course under the pretense of necessary reduction of expenses, while at the same time they are necessary reduction of expenses, while at the same time they are Resolved, That the dignity, honor, influence and success of the medical profession largely depend on the recognition of a proper organization can rightfuliy require its medical examiners to work organization can rightfuliy require its medical examin

It was further moved and carried by unanimous vote of the members present:
That members of the Sacramento Society for Medical Improvement who examine in life insurance for a fee less than that of the fee bill, whether paid in individual fees or in salary, be dropped from the roll of the societs.

That it is the sense of this societs that the rights and privileges That it is the sense of this society that the rights and privileges whose names have been dropped from the roll for examining for less than the prescribed fee.

That any special alrangement for increase of fee to $\$ 5.00$ per examination made between medical examiner and local agent shall not be accepted by this society and the special arrangement must be made between the medical director of the company and the examiner.

E. M. WILDER, M.D., Secretary.

\section{Medical Legislation}

Department of Public Health.

At a recent meeting of the Norfolk District Medical Society the enclosed resolutions were unanimously adopted:

Resolved, That the Norfolk District Medical Society of the State of Massachusetts endorses the action taken by the American Medical Association in favor of the establishment of a Department of Public Health with representation in the Cabinet of the President of the United States.

Resolved, That a certified copy of the above resolutions be forwarded by the Secretary to the Chairman of the Committee on I.egislation of the American Medical Association.

James C. D. Pigeon, Secretary.

\section{Correspondence}

The Philadelphia School for Nurses.

Orange, N. J., May 17, 1906.

To the Editor:-In a recent Bulletin of the Philadelphia School for Nurses there are given several hundred names of physicians who endorse this school. A paragraph printed at the head of these names reads as follows: "In every instance one or more letters have been received giving specific permission to use the writer's name as referesce in connection with this movement."

Under Orange, N. J., the names of eleven physicians are given, my own among that number. As I have never endorsed this school I was interested to know how many of the men named had actually done so. I find two of the men named removed from Orange more than two years ago, and $I$ understand one of them is now dead. Another is a graduate of 48 years' standing and has not engaged in practice for more than 35 years. Of the remaining eight all deny absolutely that they have endorsed the Philadelphia School for Nurses.

It does not seem that such a piece of barefaced assurance should go unchallenged, and I have no doubt that many of the names given are used without authority. Lins Emerson.

\section{Association News}

Hotel Committees in Boston.

Dr. D. D. Scannell, secretary, writes: "The headquarters of the committee on hotels and transportation will be located in a special booth at Mechanics Building. There will be here a sufficient list of suitable accommodations for those who have deferred making arrangements until the last moment. There will be a sufficient elerical force to minimize delay so far as possible. There will also be a reasonable number of messenger boys whose duty it will be to help our visitors in locating their rooms. In addition to all this, there will be at each of the four railroad stations representatives from a subcommittee who will help in the distribution of information, and for those who desire it, help to secure accommodations by telephoning to the Mechanies Building headquarters. While it is desirable, of course, that all who can should go to the Mechanics Building office, still rve can help also from these railroad stations: For those coming into Boston on the Boston and Albany railroad, or the Providence division of the New York, New Haven and Hartford, and whose hotel reservations are in the Brunswick, Buckminster, Copley Square, Lenox, Nottingham, Oxford, Somerset, Abbottsford, Vendome, Victoria or Westminster, we 